\title{
The Effects of Hyperbaric Oxygen and Active Recovery on Lactate Removal and Fatigue Index
}

\author{
Widiyanto ${ }^{1}$ and Soetanto Hartono ${ }^{2}$ \\ ${ }^{1}$ Yogyakarta State University, Faculty of Sport Sciences, Yogyakarta, Indonesia, ${ }^{2}$ Surabaya State University, Faculty of Sport Sciences, Surabaya, \\ Indonesia
}

\begin{abstract}
The purpose of this study was to compare active recovery and recovery using hyperbaric oxygen on lactate removal and fatigue index. Fatigue index was measured through Running-based Anaerobic Sprint Test (RAST). Lactate clearance was measured using lactate analyzer. Recovery period is important since competitive events are sometimes very close one from the other.The design of this research was randomized pretest posttest control group design. Thirty students were randomly assigned to three groups consisted of 10 students, the first group doing recovery using 1.3 ATA hyperbaric oxygen after doing RAST, the second group doing recovery in 1.8 ATA hyperbaric oxygenafter doing RAST, and the third group doing active recovery with light intensity after doing RAST. Blood lactate concentration was measured before RAST, ten minutes after RAST, and after recovery either using hyperbaric oxygen or active recovery, and then they took RAST again to get the second fatigue index. Data was analyzed through Manova with .05 significant levels. Blood lactate level isthe lowest in those treated with Hyperbaric Oxygen 1.3 ATA has significant difference with active recovery $(p=.008)$. Fatigue index of those treated with hyperbaric oxygen 1.3 ATA is the lowest (6.7 watts/second) vs HBO 1.8 ATA (7.85 watts/second) and active recovery (8.56 watts/second). Increasing oxygen supply to musculoskeletal system increases metabolism of waste substances and promotes recovery from fatigue. Hiperbaric Oxygen 1.3 ATA is more effective than HBO 1.8 ATA or active recovery in lactate removal.
\end{abstract}

Key words: hyperbaric oxygen treatment, blood lactate, fatigue index, RAST

\section{Introduction}

An excellent sport performance is supported by sport skills; strength, power, flexibility, balance, agility, speed, aerobic and anaerobic capacities, whereas anaerobic work is determined by substrate level and lactate clearance (Monedero \& Donne,2000). Increased lactate results in decreased $\mathrm{pH}$ and decreased enzymatic work, and eventually ATP production is also slowered, and this condition will cause fatique and inhibit sport performance. So, optimal recovery process and accelerated lactate clearance would be of benefit to support sport performance. Optimalization of recovery is important to reduce fatique, to increase physiological adaptation to training and to reduce injury risks (Dupont \& Moalla, 2004), especially in series competition. Accoding to Falks, Einbinder, Weinstein,
Epstein and Karni (1995), lactate clearance is very important, and is done by increasing blood flow, and increasing lactate transport to form ATP again, so acceleration of lactate metabolism is crucial. Recovery activity dictates the speed by which lactate is metabolized in muscles as well as in the liver. Anaerobic work induces lactate production, and increase lactate production will decrease $\mathrm{pH}$, and ATP production as well, and this eventually results in fatique, so fast recovery and acceleration of lactate metabolism is necessary for performance maintainance. Optimalization of recovery technique will increase physiological adaptation to sport performance and avoidance of sport injuries (Dupont \& Moalla, 2004).

One among several methodes of recovery is using hyperbaric oxygen. Several studies have shown that passive rest in

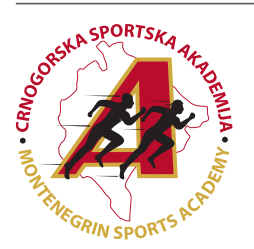

Correspondence: 
hyperbaric oxygen chamber able to speed up lactic acid clearance in the blood (Untari, 2003). Athlete conditioning should be done not only during training, but also during competition, and in between competition (Lattier \& Millet, 2004). Hyperbaric oxygen has been used for recovey after high intensity activities. Hyperbaric oxygen is able to increase oxygen transport untill tissue level, to increase respiratory function as well as nervous function (Jain, 1996). The primary function of hyperbaric oxygen therapy is to accelerate the recovery of soft tissue by means of reducing local hypoxia, inflammation and edema (Staples \& Clement, 1996). Draper and Whyte (1997) developed the Running-based Anaerobic Sprint Test (RAST).

\section{Methods}

The design of this study was randomized pretest posttest control group design. Thirty badminton student players were randomly selected and randomly assigned to three groups consisted of 10 people. Subject characteristics; all sample were male badminton players, students of School of Sport Sciences, Surabaya State University. The age ranged from 19 to 23 years old. All three groups were doing Running-based Anaerobic Sprint Test (RAST) developed by Draper and Whyte (1997) after 10 minutes warming up. The first group was doing post exercise recovery in hyperbaric oxygen chamber with 1.3 atmospheric pressure (1.3 ATA) for 15 minutes after anaerobic test using RAST, the second group was doing post exercise recovery in hyperbaric oxygen chamber with 1.8 atmospheric pressure (1.8 ATA) for 15 minutes after anaerobic test using RAST, and the third group was doing active recovery (jogging) for 15 minutes after anaerobic test using RAST. Blood lactic acid was measured using lactate analyzer. To measure the effectiveness of hyperbaric oygen as well as active recovery on fatique index, the whole sample were doing Running-based Anaerobic Sprint Test (RAST) for the second time.

Kolmogorov-Smirnov was used to test normality of sample, and Box's Test of Equality was used to test sample homogenity. Data would be analyzed using appropriate statistics.

This study was approved in advance by Surabaya State University Board of Ethics with approval number: 10615.IO. Each participant voluntarily provided written informed consent before participating the study

\section{Results}

Kolmogorov Smirnov test shows $\mathrm{p}=.58(>.05)$, and Box's equality test shows $\mathrm{p}=.138$ (>.05), so sample is normal and homogen. Table 1 shows that blood lactate level is significantly

Table 1. Blood lactic acid concentration after recovery in HBO 1.3 and 1.8, and active recovery, and fatique index after second time doing RAST

\begin{tabular}{|c|c|c|c|c|c|c|c|}
\hline \multirow{2}{*}{$\begin{array}{l}\text { Dependent } \\
\text { Variable }\end{array}$} & \multirow{2}{*}{ (I) } & \multirow{2}{*}{ (J) } & \multirow{2}{*}{$\begin{array}{c}\text { Mean } \\
\text { Difference } \\
(I-J)\end{array}$} & \multirow{2}{*}{ Std. Error } & \multirow{2}{*}{ Sig. } & \multicolumn{2}{|c|}{$\begin{array}{l}\text { 95\% Confidence } \\
\text { Interval }\end{array}$} \\
\hline & & & & & & $\begin{array}{l}\text { Lower } \\
\text { Bound }\end{array}$ & $\begin{array}{l}\text { Upper } \\
\text { Bound }\end{array}$ \\
\hline \multirow{6}{*}{$\begin{array}{l}\text { Blood lactic } \\
\text { acid }\end{array}$} & \multirow{2}{*}{$\begin{array}{l}\text { HBO } 1.3 \\
\text { ATA }\end{array}$} & HBO 1.8 ATA & 1.0400 & .91009 & .263 & -.8273 & 2.9073 \\
\hline & & Active recovery & $2.6200^{*}$ & .91009 & .008 & .7527 & 4.4873 \\
\hline & \multirow{2}{*}{$\begin{array}{l}\text { HBO } 1.8 \\
\text { ATA }\end{array}$} & HBO 1.3 ATA & -1.0400 & .91009 & .263 & -2.9073 & .8273 \\
\hline & & Active recovery & 1.5800 & .91009 & .094 & -.2873 & 3.4473 \\
\hline & \multirow{2}{*}{$\begin{array}{l}\text { Active } \\
\text { recovery }\end{array}$} & HBO 1.3 ATA & $-2.6200^{*}$ & .91009 & .008 & -4.4873 & -.7527 \\
\hline & & HBO 1.8 ATA & -1.5800 & .91009 & .094 & -3.4473 & .2873 \\
\hline \multirow{6}{*}{$\begin{array}{l}\text { Fatique } \\
\text { Index }\end{array}$} & \multirow{2}{*}{$\begin{array}{l}\text { HBO } 1.3 \\
\text { ATA }\end{array}$} & HBO 1.8 ATA & -.5428 & .94273 & .570 & -2.4771 & 1.3915 \\
\hline & & Active recovery & -1.7317 & .94273 & .077 & -3.6660 & .2026 \\
\hline & \multirow{2}{*}{$\begin{array}{l}\text { HBO } 1.8 \\
\text { ATA }\end{array}$} & HBO 1.3 ATA & .5428 & .94273 & .570 & -1.3915 & 2.4771 \\
\hline & & Active recovery & -1.1889 & .94273 & .218 & -3.1232 & .7454 \\
\hline & \multirow{2}{*}{$\begin{array}{l}\text { Active } \\
\text { recovery }\end{array}$} & HBO 1.3 ATA & 1.7317 & .94273 & .077 & -.2026 & 3.6660 \\
\hline & & HBO 1.8 ATA & 1.1889 & .94273 & .218 & -.7454 & 3.1232 \\
\hline
\end{tabular}

different in group treated with HBO 1.3 against active recovery $(\mathrm{p}=.008)$, group treated with HBO 1.8 is not significantly different with active recovery $(\mathrm{p}=.94)$, and group treated with
HBO 1.3 is not significantly different with HBO 1.8 as well $(p=.263)$, so HBO 1.3 is significantly effective in reducing blood lactate compared with $\mathrm{HBO} 1.8$ and active recovery.

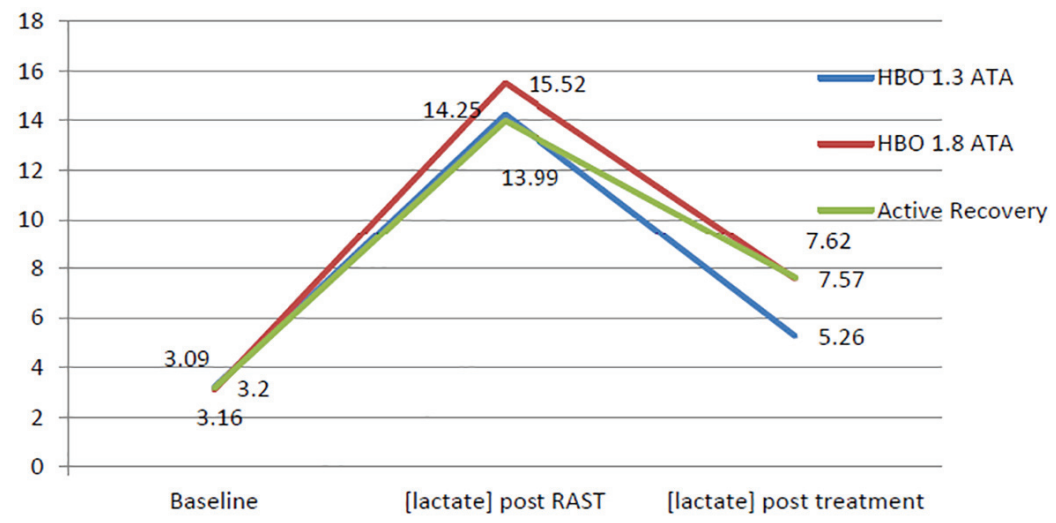

Figure 1. Blood lactate concentration in $\mathrm{mMol} / \mathrm{L}$ during start of exercise, 10 minutes after RAST, and after recovery 
Fatigue index after doing second RAST does not show any significant difference among those three treatment, HBO 1.3 vs HBO $1.8(\mathrm{p}=.570)$, HBO 1.3 vs active recovery $(\mathrm{p}=.077)$, and HBO 1.8 vs active recovery $(\mathrm{p}=.218)$.

Figure 1 shows that after treatment with $\mathrm{HBO} 1.3, \mathrm{HBO}$ 1.8 , and active recovery, blood lactate concentration after HBO 1.3 treatment is $5.26 \mathrm{mMol} / \mathrm{L}$, significantly different with active recovery ( $5.26 \mathrm{mMl} / \mathrm{L}$ vs $7.62 \mathrm{mMol} / \mathrm{L} ; \mathrm{p}=.008)$, but not with $\mathrm{HBO} 1.8$ (5.26 mMol/L vs $7.57 \mathrm{mMol} / \mathrm{L} ; \mathrm{p}=.263)$. HBO
1.8 is not significantly different with active recovery $(7.57$ $\mathrm{mMol} / \mathrm{L}$ vs $7.62 \mathrm{mMol} / \mathrm{L} ; \mathrm{p}=.94$ ).

Figure 2 shows fatigue index after doing RAST for the second time. Hyperbaric oxygen treatment using 1.3 ATA shows fatigue index of 6.7 watts/second, HBO 1.8 treatment shows 7.85 watts/second, whereas active racovery shows 8.56 . So, HBO 1.3 produces the lowest fatigue index, meaning the least fatigue although comparisons of those three treatments against each other are not significantly different.

\section{Fatigue Index Graph}

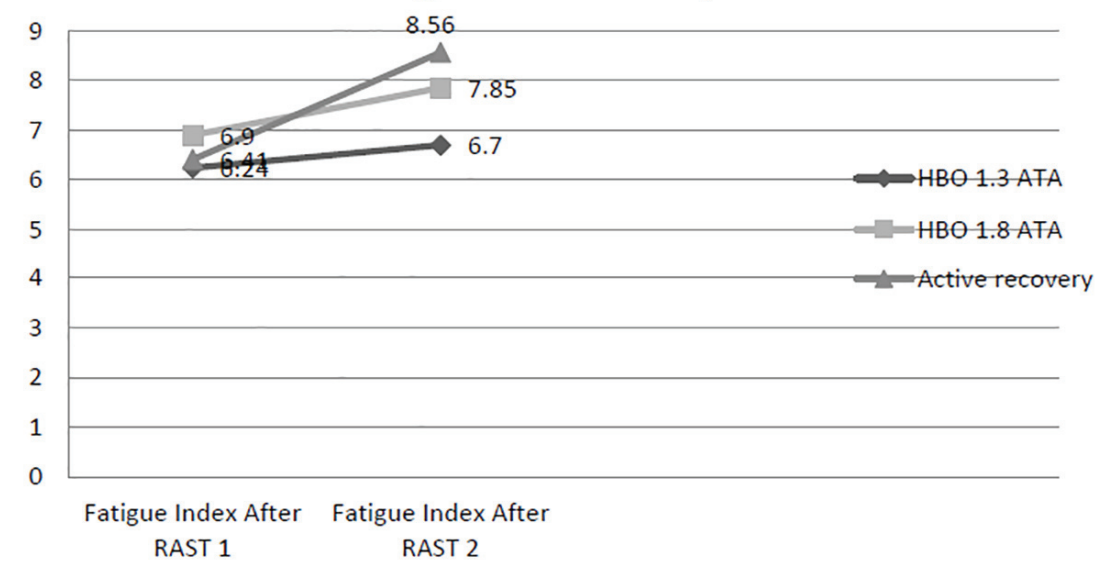

Figure 2. Fatique index in watts/second after doing the first RAST and the second RAST

\section{Discussion}

This study indicates that mild pressure of hyperbaric oxygen therapy (1.3 ATA) reduces blood lactate concentration significantly against active recovery, and eventhough there is a non significant difference in fatique index in second RAST, the score of mild hyperbaric oxygen therapy (1.3 ATA) is the lowest, indicating that it has a tendency to be more effective.

A continuous supply of oxygen to all tissues is necessary for the efficient production of ATP, and this supply is considered sufficient when aerobic metabolism is maintained (Robertson \& Hart, 1999). By performing HBO treatment, more oxygen is dissolved in the plasma, increasing the oxygen reaching the peripheral tissues as well as increasing $\mathrm{PaO} 2$. HBO treatment is therefore expected to improve recovery from injury and fatigue (Ishii et al., 2005). Other study of mild pressure hyperbaric oxygen therapy using 1.3 ATA reduces oxidative stress as indicated by a significant decrease in serum reactive oxygen metabolites $(\mathrm{p}=.006)$, and a significant decrease of fatique as indicated by visual analog scale scores from 5.0 to 2.1 ( $\mathrm{p}<.001)$ (Kim, Yukishita, \& Lee, 2011). Studying the effects of hyperbaric oxygen on muscle fatigue. Shimoda, Enomoto, Horie, Miyakawa and Yagishita (2015) came to a conclusion that hyperbaric oxygen treatment contributes to sustained force production due to suppressing the muscle fatigue progression. In fact, HBO treatment has effectively increased recovery from fatigue. This was clearly seen at the Nagano Winter Olympics, where sports players experiencing fatigue were successfully treated, enabling the players to continue performing in the games (Ishii et al., 2005).

After high intensity exercise which is an anaerobic work, condition in working muscle is slightly hypoxic since oxygen is used intensively to change the ischemic condition of the working muscle and to metabolize lactate, and as a result oxygen pressure in the tissue drops. The haemodynamic and microcirculatory effects of hyperbaric oxygen appear to be effective in compensating ischemic conditions. Oxygen pressure in the tissues increase to levels close to normal. Hyperbaric oxygen causes vasoconstriction with a decrease in microcirculatory blood flow but with no decrease of oxygen pressure in the tissue. This reflexed vasoconstriction is useful to avoid hyperoxic condition with many bad consequences including tissue oxidation (Mathieu, 2009). Increasing oxygen supply to musculoskeletal system increases metabolism of waste substances and promotes recovery from fatigue. Hiperbaric Oxygen 1.3 ATA is more effective than HBO 1.8 ATA or active recovery in lactate removal.This study shows that HBO 1.3 ATA is optimal in bringing effective tissue oxygenation.

\section{Acknowledgements}

We appreciate support from Surabaya Naval Hospital for providing access to Hyperbaric Oxygen Chamber.

\section{Conflict of Interest}

The authors declare that there are no conflicts of interest.

Received: 21 June 2018 | Accepted: 24 August 2018 | Published: 01 October 2018

\section{References}

Draper, N. \& Whyte, G. (1997). Here's a new running base test of anaerobic performance for which you need only a stop watch and a calculator. Peak Performance, 96, 3-5.

Dupont, G. \& Moalla, W. (2004). Passive versus active recovery during high-intensity intermittent exercises. Medicine \& Science in Sports \& Exercise, 36(2), 302-307.

Falks, B., Einbinder, M., Weinstein, Y., Epstein, S., \& Karni, Y.(1995). Blood lactate concentration following exercise: Effect of heat exposure and of active recovery in heat-acclimatized subjects. International Journal of Sport Medicine, 16(1), 7-12.

Ishii, Y., Deie, M., Adachi, Y., Yasunaga, Y., Sharman, P., Miyanaga, Y., \& Ochi, M. (2005). Hyperbaric oxygen as an adjuvant for athletes. Sports Med, 35(9), 739-746.

Jain, K.K. (1996). Texbook of Hyperbaric Medicine" 2nd Revised Edition, Hogrefe and Hubber Publisher Inc. (432-445). 
Kim, S., Yukishita, T., Lee, K., Yokota, S., Nakata, K., Suzuki, D., \& Kobayashi, $\mathrm{H}$. (2011). The effect of mild-pressure hyperbaric therapy (oasis $\mathrm{O}_{2}$ ) on fatigue and oxidative stress. Health Today, 3(7), 432-436.

Lattier, G. \& Millet, G.Y. (2004). Fatigue and recovery after high-intensity exercise part II: recovery interventions. InternationalJournal of Sports Medicine, 25(7), 509-515.

Mathieu, D. (2006). Handbook on Hyperbaric Medicine: Physiologic Effects of Hyperbaric Oxygen on Hemodynamics and Microcirculation, ed. (75101). Springer. Printed in the Netherlands.

Monedero, J. \& Donne, B. (2000). Effect of recovery interventions on lactate removal and subsequent performance. International Journal of Sports
Medicine, 21(8), 593-597.

Robertson, P.W. \& Hart, B.B. (1999). Assessment of tissue oxygenation. Respir Care Clin N Am, 5(2), 221-63.

Shimoda, M., Enomoto, M., Horie, M., Miyakawa, S., \& Yagishita, K. (2015) Effects of hyperbaric oxygen after maximal intermittent plantar flexion exercise. J of Strength Con Res, 29(6), 1648-56.

Staples, J. \& Clement, D. (1996). Hyperbaric oxygen chambers and the treatment of sports injuries. Sports Med., 22(4), 219-227.

Untari. (2003). The effects of hyperbaric oxygen on blood lactate concentration and arterial $\mathrm{pCO}_{2}$ after submaximal workload.Master thesis. Graduate Program, Airlangga University (in Indonesian). 